\title{
An alternative perspective for acquisitions of amber from Myanmar including recommendations of the United Nations Human Rights Council
}

\author{
Adolf Perettio
}

\begin{abstract}
Recent publications have been actively recommending strong embargos on Burmese amber trade and research. Although the motivation of these actions seeks to prevent armed groups from obtaining capital via amber trade, which in the views of the authors helps further fueling the armed conflict, here, I demonstrate that this claim is not accurate. In this analysis, I prove that these preventative actions undertaken by the Society of Vertebrate Paleontology and echoed by others do not resolve the situation in Burma, but on the contrary, aggravate the problem by negatively affecting the Burmese miners. My analysis is congruent with other independent analyses of the Burmese Amber trade. In line with the recommendation of the United Nations, and as an alternative approach, it is possible to support the amber economy that is in opposition to the Burmese military and help the Burmese scientific community to increase their capability and knowledge to engage in a niche market that is largely not accessible to unethical players. This would lead to a sourcing of research material that fulfills the demand of the international scientific community for ethical standards.
\end{abstract}

Keywords: Amber, Burmite, Burma, Ethical mining, Human rights, Armed conflict

\section{Main Text}

A recent correspondence to Nature (Engel 2020) echoes a communication by the directors of the Society of Vertebrate Paleontology (SVP) where they recommend to editors from over 300 journals around the world to ban submissions of research projects based on amber specimens acquired from Myanmar after June 2017 (Rayfield et al. 2020a). There are a number of reasons the United Nations Fact-Finding Mission (United Nations Human Rights Council 2019 and 2020) on natural resources in Myanmar and a separate, recent private fact-finding mission on the amber trade have not recommended a ban on Burmese amber acquisitions even after 2017 (Peretti 2020).

Correspondence: adolf@peretti.ch

Peretti Museum Foundation and GRS Gemresearch Swisslab AG, Meggen, Switzerland

Springer Open
In the course of the last month, I have studied the arguments made within the industry about the amber issue and Dr. Engel's proposal that researchers stop acquiring Burmese amber until the conflict in Myanmar is resolved, while allowing research on collections built before 2017. By making that notion Dr. Engel ignores important new developments that have taken place in respect to the discussion regarding Burmese amber. Among the different amber mines distributed all over Myanmar (Peretti 2020), Dr. Engel is actually commenting only on the mines in the vicinity of Tanai, in the Hukawng Valley in Northern Myanmar while ignoring other non-conflict amber mines in Myanmar. Dr. Engel referred to an April 2020 letter issued by directors of the SVP (Rayfield et al. 2020a) regarding perceived and potential human rights issues associated with the mining, trade, and research of Burmese amber, and which called

(c) The Author(s). 2021 Open Access This article is licensed under a Creative Commons Attribution 4.0 International License, which permits use, sharing, adaptation, distribution and reproduction in any medium or format, as long as you give appropriate credit to the original author(s) and the source, provide a link to the Creative Commons licence, and indicate if changes were made. The images or other third party material in this article are included in the article's Creative Commons licence, unless indicated otherwise in a credit line to the material. If material is not included in the article's Creative Commons licence and your intended use is not permitted by statutory regulation or exceeds the permitted use, you will need to obtain permission directly from the copyright holder. To view a copy of this licence, visit http://creativecommons.org/licenses/by/4.0/. 
on journal editors to boycott submissions related to Burmese amber acquired after June 2017 (Rayfield et al. 2020a). Dr. Engel's letter, however, ignores the fact that the SVP board of directors has since updated its recommendations on the matter, including an acknowledgement that amber produced since 2017 can, in fact, be ethically acquired, although under special conditions (Rayfield et al. 2020b).

The SVP referenced several investigations in updating its recommendations, among the most important being the UN Fact-Finding Mission (United Nations Human Rights Council 2019, 2020, UNHRC hereafter), which reported on how the Burmese military had used Myanmar's natural resources to fuel conflict, primarily jade and ruby gemstones. The UNHRC also mentions the opinion of persons tortured by the armed forces, indicating that the military (Tatmadaw) seized control of the amber mines in the Tanai township to undermine the Kachin Independence Army's mining resources. The UNHRC report mentions that Myanmar's constitution recognizes military as an autonomous institution, free from any civilian control and oversight, and that their alternative sources of revenue (not only gemstone extraction, but construction, manufacturing, insurance, tourism, and banking) are used in grave human rights violations. The UNHRC report calls for an amendment of the constitution to place the military under civilian control, and in the meantime calls on businesses not to work with the military. The UNHRC report listed the key military/government and associated private players within the amber-buying network that should be avoided, while they reassure that acquisitions of natural resources in Myanmar should be allowed to continue, but only when such dealings are conducted through the network that is in opposition to the Burmese military. The UNHRC report strongly advocates for responsible business policies and practices which put human rights first. Details regarding the situation at the amber mines can be found in the 42nd Human rights council session (United Nations Human Rights Council 2019) and for a selection of citations and a review of that session see Peretti (2020).

The timeframe of events in Tanai shows that before 2017, the production of Burmese amber was at its highest, and the Burmese military had set up operations to actually stop amber production that the military had determined its adversary, the Kachin Independence Army (KIA), was using to fuel its fight against the military (Poinar 2019, United Nations Human Rights Council 2019, Peretti 2020).

The recommendation by Dr. Engel to exempt amber collections acquired pre-2017 as a "safe bet", implying they need not be scrutinized for ethical compliance is not a reasonable assessment when confronted with the facts on the ground. If there is any amber production that has been witnessed by us to have fed the conflict in Myanmar, then it is the 2016 to before February 2018 amber production that was controlled by the KIA (United Nations Human Rights Council 2019). The elaborate methods the KIA used to control production was carried out through various licenses, taxes, restrictions on the movement of labor and enforced auctions - all of which was investigated by us in a fact-finding mission to the region in February 2018, just weeks before the final military offensive (Peretti 2020). The findings are also confirmed by a recently published conflict analysis (Poinar and Ellenberger 2020). A detailed reporting of these events and review of the UN Fact-Finding Mission's guidelines can be accessed elsewhere (Peretti 2020).

In a recent investigation of the ethics associated with Myanmar amber (Peretti 2020), I documented that amber production moved away from Tanai to a nonconflict zone in the Khamti area, which is $100 \mathrm{~km}$ to the south-south west (Fig. 1). I have verified the non-conflict status of the Khamti mine. The mine operations in the Khamti area are dominated by a single mining operation, Sea Sun Star (Nyunt et al. 2019, Peretti 2020). Furthermore, to this date, I was able to validate that none of the persons and companies listed in the UNHRC report as being involved in the Myanmar conflict (United Nations Human Rights Council 2019), are operating Khamti mining area (details available from the Peretti Museum Foundation).

The amber production of the Tanai mines declined, and a significant proportion of the amber mining population was forced into internally displaced persons (IDP) camps around Tanai and Myitkyina. Based on visits from GRS gemologists to these IDP camps and surrounding areas during 2017 and 2018, I was able to validate that the former local mining community developed a veritable cutting industry (Fig. 2), supported by amber from mines in non-conflict zones as well as old stock and remaining production of the mines of the Tanai area. In fact, IDP camps were put in place already for over a decade - these camps have gradually developed amber cutting practices over a long period of time, considering that conflict in the area pre-dates the events that unfolded after 2017. Based on my own observations, I determined that these camps generate significant profit based on amber cutting activities. Furthermore, people in these camps have access to local markets where they can trade their products in the close vicinity of the markets (Peretti 2020). The importance of the amber cutting centers at IDP camps must, according to our opinion, be regularly revisited as camps are sometimes relocated or dissolved. 


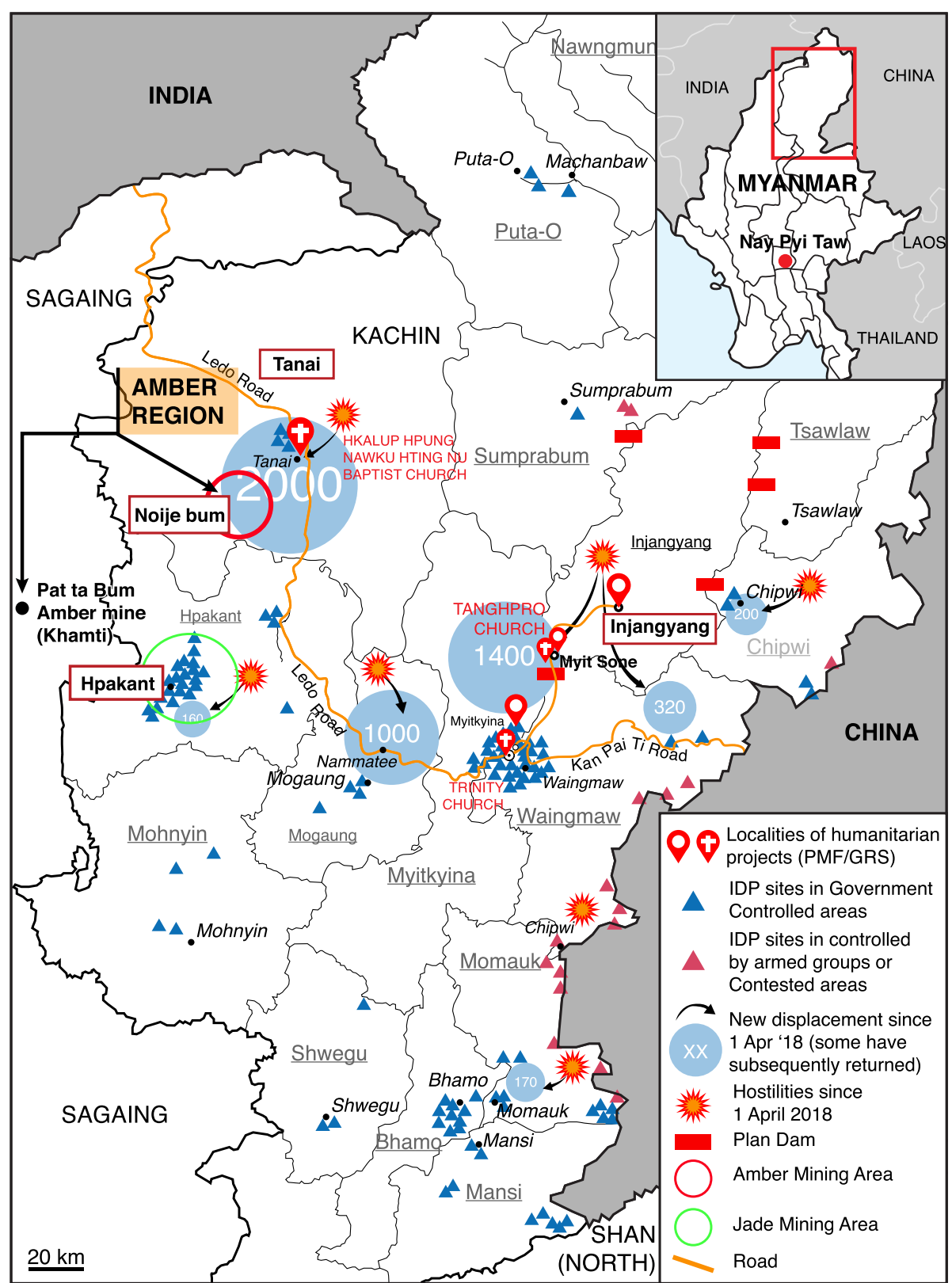

Fig. 1 Map of the North of Myanmar, modified from Ji (2019) to indicate of different mining districts, conflict areas, internally displaced person camps (IDP), and areas with humanitarian projects. These projects were initiated in the year 2018 by the author in cooperation with the Trinity Baptist Church outside of Myitkyina, the Myitsone RC Church and the Baptist Church near Tanai for people fleeing from Injangyang township, and the amber mining area (Peretti, 2020). These are the areas with detailed insider information available to the author. Red squares indicate conflict locations mentioned in a UNHRC Report (United Nations Human Rights Council. 2019)

While the profits of amber production in general sometimes end up in the war chests of opposing parties in the civil wars in Myanmar, it is illogical that the trade and surge in interest involving vertebrate fossils for example has in part fueled conflict by the commercial trading of amber (Rayfield et al. 2020a). The analysis of 14 Myanmar government operated auctions on government gemstone production including amber between 2015 and 2019 proves this contention (Peretti 2020). The analysis found that only $0.1 \%$ of the revenues from these auctions were from amber sales, and, more importantly, not a single lot of vertebrate inclusions were auctioned - in fact, insect inclusions account for the bulk of amber fossil income (Engel 2020). An analysis of trade routes into China also indicates that the Burmese military did not profit significantly from the amber mining (Poinar and Ellenberger 2020). 


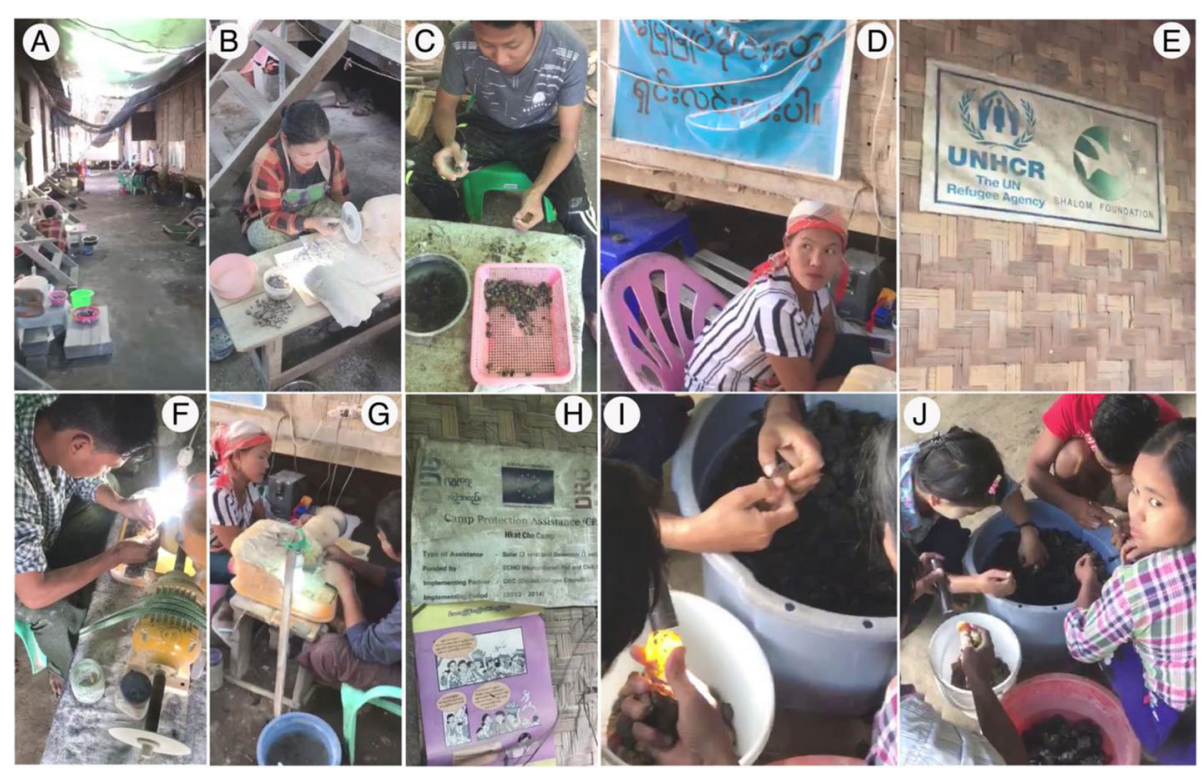

Fig. 2 a-j Example of gemstone cutting operations at internally displaced person (IDP) camp Hkat Cho in 2018 . Each house has a cutting facility at its entrance. a Interior view of a camp alley. $\mathbf{b}-\mathbf{d}, \mathbf{f}-\mathbf{g}$ Woman and men sorting and cutting amber. $\mathbf{d}$ Banner is a protest poster by the IDP camp inhabitants demanding clearing landmines around the amber mines. e United Nations High Commissioner for Refugees banner at camp. $\mathbf{h}$ Camp protection assistant, including access to solar energy, camp name Hkat Cho and date of solar installation 2013-2014 shows IDP camp predates conflict period of 2017-2018. i-j Member of a family working together in the sorting process. Pictures by the authors agent

Important paleontological samples cannot be found in the general production scheme as they are not typically observable in amber rough. These specimens are usually discovered during the cutting process (Peretti 2020). Furthermore, based on estimates derived from my own correspondence with the mining and cutting community, significant vertebrate remains in amber are so rare that they are discovered only in one from every one million amber pieces that are polished (Peretti 2020). The economic value of fossilized vertebrate remains is therefore negligible relative to the amber gem trade and is not an economic driver for amber production. It is rather a driver of additional profits for educated members of the local population.

Before 2017, about 200,000 miners were working in the mines in Tanai, with the number dropping to about 20,000 or even fewer after military operations in 2018 (Peretti 2020; Poinar and Ellenberger 2020). Consequently, this left a large workforce that transitioned into the secondary, amber cutting industry - the source of scientifically important fossilized remains. Indigenous people working in IDP camps are directly involved in the scientific process, playing the important role of finding and sorting amber inclusions. These findings are the basis for over 700 important discoveries that have been published in scientific publications (Ross 2019). The bulk of these material have been found prior to 2017 by amber cutters in IDP camps, adjacent cities, and towns, which generated income for their families, and more importantly under humanitarian and non-conflict conditions
(Peretti 2020). These practices are ongoing today, creating an important market of burmite fossils that benefit disadvantaged communities.

Even if the mass production of amber (not the specialized discovery market) may potentially be misused by the various parties in the conflict zone as a contribution to the war effort, the discovery of paleontological samples stands alone as a niche market controlled by experts and not by the Burmese military (Peretti 2020). It is true that the Burmese situation is very complex but implementing a general ban on amber trade and Burmese amber research is an easy and quick fix, although according to the opinion of the United Nations FactFinding mission report, not the recommended one.

Recent publications condemning amber trade create awareness of the problem but contribute little to improve current conditions. The paleontological community should acknowledge the hard work of Burmese miners (Fig. 3) instead of censuring the whole process. It is true that the current situation is far from perfect (e.g., mining practices are devastating for the environment, and many valuable pieces fail to make it to Museums, and sadly end up in private hands), but reproving these practices will only aggravate the problem. Actions speak louder than words; therefore, the scientific community should help by channeling positive actions instead of creating obstacles. Improving the current situation in Myanmar can be accomplished by declaring Burmese amber mines as World Heritage Sites, where mining could be highly regulated, the geology 


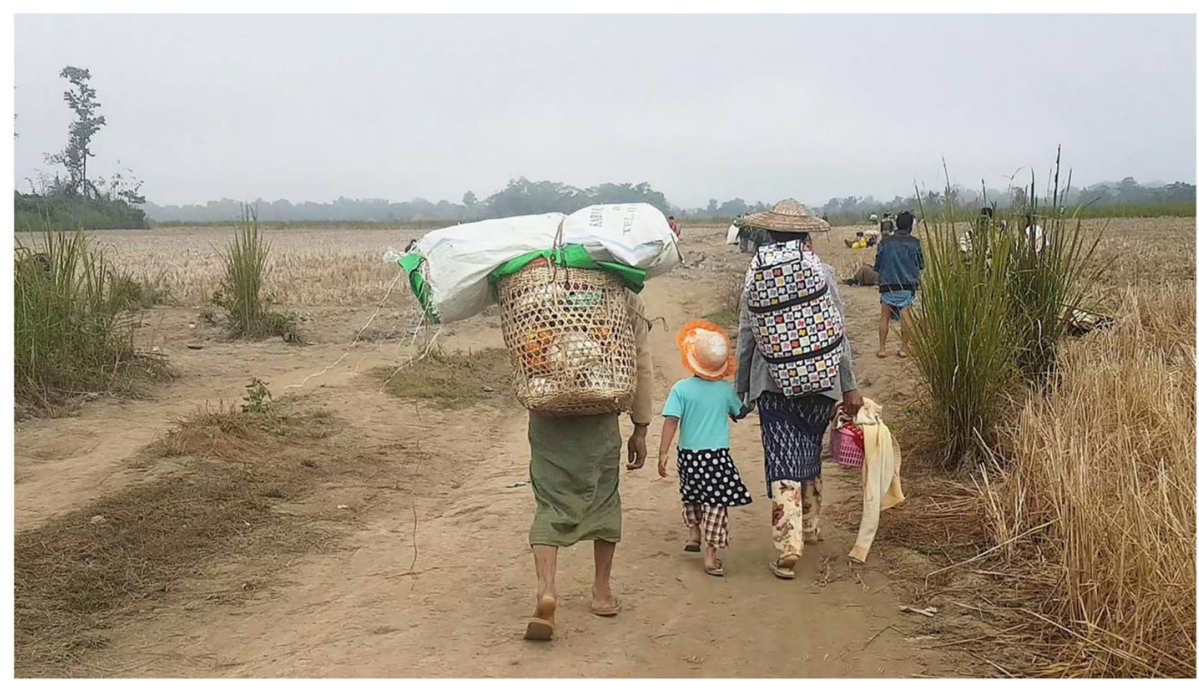

Fig. 3 A Burmese family from an internally displaced person (IDP) camp head to an amber mine at Mine Khun, near Tanai, in December 2017. They carry the minimal provisions, including a green tent and the illusion of an income from amber mining

contextualized, and some outcrops preserved. In the long run, these responsible practices can generate important collections in scientific institutions, representing this rich fossil region, and creating a remarkable resource to educate local communities and foreign tourists. The proposed bans and moratoria can only lead to further exploitation of these limited resources and miner communities. Instead, an effort must be made to continue the steady purchase of samples in order to support these communities, following the guidelines of the United Nations and including rigorous due diligence. The scientific community can also support local workers, so that Burmese researchers can partake in the process of discovery and receive direct recognition for their contributions to science.

Finally, branding the amber from Myanmar as "conflict amber" is harmful to the indigenous people who have made numerous attempts to reclaim the mines and leave the IDP camps to resume doing what they most want to do - working in the same mines (Ji 2019). Getting in contact with these people is possible through private initiatives, including the mediation of local churches, as shown in recently published case studies (Peretti 2020).

Under this framework of the continuous acquisition of amber from Myanmar, it is then possible to realize and give credit to Dr. Engel's vision - that is, to build a scientific community in Myanmar by training local paleontologists and making Myanmar the center of new discoveries (Engel 2020). The Burmese cutters and miners should, indeed, be rewarded for their hard work in the middle market. However, this sector also requires the capital of the free market to operate, regulated through the demands of the world for rigorous ethical oversight and due diligence processes - and not be laid to waste by any generalized ban on amber trade and research activity.
Once the ethical procedures are put in place, the enormous importance of Burmese amber to science should be preserved as it has already been petitioned in detail elsewhere, by views of a large number of stakeholders of the scientific community, in response and contrary in opinion to the same SVP letter that Dr. Engel is referring to (Haug et al. 2020).

There are new initiatives arising from within Myanmar's private sector, facilitating the possibility to directly interact with Burmese gem companies and to subsequently receive export permissions. An example of such a development is an NGO non-profit initiative in Yangon (https://gjeayangon.com/aboutevent/) that specializes in organizing trade fairs in Yangon where international buyers can directly interact with exhibiting Burmese miners. This allows scrutinizing of the participating amber suppliers using the list of banned companies and recommendations of the UNHRC Fact-Finding Mission in Myanmar and to establish due diligence procedures and ethical criteria. Special attention should also be made on demanding the preservation and restoration of nature during the mining process. This opens up an opportunity for the ethical sourcing of amber material from Myanmar.

\section{Acknowledgements}

I want to thank all the persons involved in the GRS Gemresearch

humanitarian campaigns in Myanmar from 2017 to 2019, and local people that provide support over the last 20 years. I have interacted with many persons while working in this area, and I want to specially recognize the help of 2 anonymous Burmese field gemologists and the priests of local churches. Many areas were restricted to me, and without the effort of the local Burmese population and miners, as well as IDP camp inhabitants, it would not have been possible to achieve an informed firsthand opinion. I am grateful with Joseph Bevitt (Australian Centre for Neutron Scattering, Australian Nuclear Science and Technology Organisation, Australia), Luis M. Chiappe (Natural History Museum of Los Angeles, USA), Juan Diego Daza (Sam Houston State University, USA), and two anonymous reviewers for their feedback, which greatly improved the quality of this manuscript. I also thank Emily J. Rayfield (University of Bristol, Bristol, UK) for her correspondence on further ideas about the concerns from the Society of Vertebrate 
Paleontology on Burmese Amber Research. This report was written prior to the recent events including the ongoing military coup and recent conflicts with the civil society in Burma. Major future developments in IDP camps and amber mines may be carefully monitored. I would like to thank the Swiss Government for the decision to directly supervise the Peretti Museum Foundation (PMF) at the state level and to grant permission that funds of PMF can officially be used to support scientists and the population in the mining areas where the foundation's objects were found.

\section{Author's contributions}

NA. The author read and approved the final manuscript.

\section{Funding}

Personal funds, GRS GemResearch Swisslab AG, and Peretti Museum Foundation.

\section{Availability of data and materials}

All information is available in the manuscript and the cited references.

\section{Declarations}

\section{Competing interests}

The author declares no competing interest.

Received: 4 November 2020 Accepted: 26 April 2021

Published online: 24 May 2021

\section{References}

Engel MS (2020) Myanmar: paleontologists must stop buying conflict amber. Nature 584(7822):525. https://doi.org/10.1038/d41586-020-02432-z

Haug J, Azar D, Ross A, Szwedo J, Wang B, Arillo A, Baranov V, Bechteler J, Beutel R, Blagoderov V, Delclòs X, Dunlop J, Feldberg K, Feldmann R, Foth C, Fraaije RHB, Gehler A, Harms D, Hedenäs L, Hyžný M, Jagt JWM, Jagt-Yazykova EA, Jarzembowski E, Kerp H, Khine PK, Kirejtshuk AG, Klug C, Kopylov DS, Kotthoff U, Kriwet J, McKellar RC, Nel A, Neumann C, Nützel A, Peñalver E, Perrichot V, Pint A, Ragazzi E, Regalado L, Reich M, Rikkinen J, Sadowski E-M, Schmidt AR, Schneider H, Schram FR, Schweigert G, Selden P, Seyfullah $\sqcup$, Solórzano-Kraemer MM, Stilwell JD, van Bakel BWM, Vega FJ, Wang Y, Xing $L$ (2020) Comment on the letter of the Society of Vertebrate Paleontology (SVP) dated April 21, 2020 regarding "Fossils from conflict zones and reproducibility of fossil-based scientific data": Myanmar amber. PalZ 94(3):431-437. https:/doi.org/10.1007/s12542-020-00524-9

Ji T (2019) Blood amber - military resource grab clears out indigenous peoples in Kachin State's Hukwaung Valley. Online Burma/Myanmar Library. Kachin Development Networking Group (KDNG) Available at: https://kdng.org/2019/ 08/19/blood-amber/.

Nyunt TT, Sun TT, Choo C, Kyaw NBB, Aung WYL (2019). Amber from Khamti, Sagaing Region, Myanmar. Poster Session of the 36th International Gemmological Conference, Nantes.

Peretti A (2020) Ethical guidelines for Burmese amber acquisitions. J Appl Ethical Mining Nat Resour Paleontol 1(2020):4-78 Available at www.pmf.org/journal

Poinar G, Ellenberger S (2020) Burmese amber fossils, mining, sales and profits. Geoconservation Res 3(1):12-16

Rayfield EJ, Theodor JM, Polly D (2020a) Fossils from conflict zones and reproducibility of fossil-based scientific data. Available online. https://www. vertpaleo.org/wp-content/uploads/2021/01/SVP-Letter-to-Editors-FINAL.pdf.

Rayfield EJ, Theodor JM, Polly D. (2020b) Further information on Myanmar amber, mining, human rights violations, and amber trade. Available online https:// vertpaleo.org/wp-content/uploads/2021/02/Amber-Resources.pdf.

Ross AJ (2019) Burmese (Myanmar) amber checklist and bibliography 2018. Palaeoentomology 2(1):1-22

United Nations Human Rights Council (2019) Independent international factfinding mission on Myanmar. Human Right Council Forty-second Session, United Nations Available at: https://www.ohchr.org/EN/HRBodies/HRC/Mya nmarFFM/Pages/ReportHRC42thSession.aspx.

United Nations Human Rights Council. 2020 Independent international factfinding mission on Myanmar. Available at: https:/www.ohchr.org/en/ hrbodies/hrc/myanmarffm/pages/index.aspx.

\section{Publisher's Note}

Springer Nature remains neutral with regard to jurisdictional claims in published maps and institutional affiliations.

\section{Submit your manuscript to a SpringerOpen ${ }^{\circ}$ journal and benefit from:}

- Convenient online submission

- Rigorous peer review

- Open access: articles freely available online

- High visibility within the field

- Retaining the copyright to your article

Submit your next manuscript at $\boldsymbol{\nabla}$ springeropen.com 